\title{
PENGARUH PENERAPAN PROGRAM PERENCANAAN PERSALINAN DAN PENCEGAHAN KOMPLIKASI (P4K) TERHADAP KEMATIAN NEONATAL
}

\author{
Homsiatur Rohmatin ${ }^{1}$, Agustina Widayati ${ }^{2}$ \\ Akademi Kebidanan Hafshawaty Zainul Hasan Genggong \\ email: homsiatur.rohmatin@yahoo.com
}

\begin{abstract}
Abstrak
Program Perencanaan Persalinan dan Pencegahan Komplikasi (P4K) merupakan program pemerintah dalam penurunan angka kematian ibu dan bayi baru lahir. Angka kematian bayi $(A K B)$ di Indonesia masih tinggi dimana Kabupaten Probolinggo merupakan salah satu penyumbang tertinggi. P4K merupakan tanggung jawab bidan, ibu hamil, suami, dan keluarga. Masih tingginya kematian neonatal di Kabupaten Probolinggo, diduga karena kurangnya peran aktif ibu, suami, dan keluarga dalam penerapan P4K. Penelitian ini bertujuan menganalisis pengaruh penerapan $P 4 K$ terhadap kematian neonatal di Kabupaten Probolinggo. Rancang bangun penelitian adalah crossectional dengan populasi seluruh ibu yang mempunyai bayi lahir hidup atau mati (usia 0-28 hari) yang mendapatkan stiker P4K. Teknik sampling menggunakan accidental sampling. Sampel penelitian ini adalah sebagian ibu yang mempunyai bayi lahir hidup atau mati (usia 0-28 hari) yang mendapatkan stiker P4K. Pengumpulan data menggunakan kuesioner dan wawancara. Uunivariat, bivariat dan multivariat digunakan dalam menganalisis data. Hasil penelitian menginformasikan sebagian besar ibu, suami, dan keluarga kurang berperan aktif. Sehingga ada pengaruh penerapan P4K terhadap kematian neonatal. Untuk itu, diperlukan peran aktif kader posyandu dalam memotivasi dan mendampingi ibu, suami dan keluarga dalam penerapan P4K sebagai upaya menurunkan kematian neonatal.
\end{abstract}

Kata kunci : P4K, kematian neonatal, stiker

\begin{abstract}
The Maternity and Complication Prevention Planning Program (P4K) is a government program in reducing maternal and newborn mortality. The infant mortality rate (IMR) in Indonesia is still high where Probolinggo District is one of the highest contributors. P4K is the responsibility of midwives, pregnant women, husbands and families. The high neonatal mortality rate in Probolinggo Regency is allegedly due to the lack of active role of mothers, husbands, and families in implementing P4K. This study aimed to analyze the effect of P4K application on neonatal mortality in Probolinggo District. The research design was crosssectional with the population of all mothers who had live or dead babies (aged 0-28 days) who received P4K stickers. The sampling technique used accidental sampling. The sample of this study was that some mothers who have babies born alive or dead (age 0-28 days) who got P4K stickers. Data collection used questionnaires and interviews. Univariate, bivariate and multivariate were used to analyze the data. The results of the study informed that most mothers, husbands, and families were less active. Therefore, there was an effect of applying P4K to neonatal mortality. It is suggested for posyandu cadres to have an active role in motivating and assisting mothers, husbands and families in implementing P4K as an effort to reduce neonatal mortality.
\end{abstract}

Keywords : P4K, neonatal mortality, sticker 


\section{PENDAHULUAN}

Kematian bayi baru lahir di Indonesia (neonatal) masih tergolong tinggi. Menurut Survei Demografi dan Kesehatan Indonesia (SDKI) (2012), Angka Kematian Neonatus (AKN) pada tahun 2012 sebesar 19 per 1.000 kelahiran hidup. Angka ini sama dengan AKN berdasarkan SDKI tahun 2007 dan hanya menurun 1 poin dibanding SDKI tahun 20022003 yaitu 20 per 1.000 kelahiran hidup (BKKN, 2013).

Kematian neonatal (0-28 hari) menjadi perhatian penting karena kematian neonatal memberi kontribusi terhadap 59\% kematian bayi (Kemenkes RI, 2016). Angka Kematian Bayi (AKB) merupakan salah satu indikator kesehatan yang paling utama pada suatu bangsa, karena berhubungan dengan berbagai faktor seperti kesehatan ibu hamil, mutu dan akses terhadap pelayanan kesehatan, kondisi sosial-ekonomi, dan berbagai praktek pelayanan kesehatan masyarakat.

AKB di Jawa Timur pada tahun 2012 sebesar 28,31 per 1.000 kelahiran hidup dan belum memenuhi target Millenium Development Goals (MDGs).Kabupaten Probolinggo merupakan salah satu penyumbang tertinggi angka kematian bayi yaitu sebesar $64,19 \%$ pada tahun 2015 . Pada tahun yang sama, Dinas Kesehatan Kabupaten Probolinggo mencatat terjadi angka kematian neonatal sebesar 111 bayi (Dinkes Kabupaten Probolinggo, 2015).

Salah satu program kesehatan yang telah dicanangkan pemerintah sejak tahun 2007 adalah Program Perencanaan Persalinan dan Pencegahan Komplikasi (P4K) dengan stiker. Program ini merupakan upaya terobosan pemerintah dalam percepatan penurunan angka kematian ibu dan bayi baru lahir. Melalui P4K dengan stiker yang ditempel di rumah ibu hamil, maka setiap ibu hamil akan tercatat, terdata dan terpantau secara tepat. Stiker P4K berisi data tentang nama ibu hamil, taksiran persalinan, penolong persalinan, tempat persalinan, pendamping persalinan, transport yang digunakan dan calon donor darah.

Dengan data dalam stiker, maka suami, keluarga, kader, dukun bersama bidan di desa dapat memantau secara intensif keadaan dan perkembangan ibu hamil untuk mendapatkan pelayanan yang sesuai standar pada saat antenatal, persalinan dan nifas, sehingga proses persalinan sampai nifas termasuk rujukannya dapat berjalan dengan aman dan selamat, tidak terjadi kesakitan dan kematian ibu serta bayi yang dilahirkan selamat dan sehat. Dengan demikian manfaat P4K yaitu meningkatkan cakupan pelayanan kesehatan ibu hamil, ibu bersalin, ibu nifas dan bayi baru lahir melalui peningkatan peran aktif keluarga dan masyarakat dalam merencanakan persalinan yang aman dan persiapan menghadapi komplikasi dan tanda bahaya kebidanan dan bayi baru lahir bagi ibu sehingga melahirkan bayi yang sehat, dapat tercapai.

Peran bidan dalam pelaksanaan P4K yaitu bidan mendata ibu hamil, bidan bersama kader atau dukun melakukan kontak dengan ibu hamil,suami dan keluarga untuk sepakat dalam pengisian stiker termasuk pemakaian $\mathrm{KB}$ pasca persalinan, bidan memberikan konseling pada ibu hamil, suami dan keluarga tentang P4K terutama dalam menyepakati isi dalam stiker sampai dengan alat kontrasepsi pasca persalinan yang harus tercatat dalam amanah persalinan yang dilakukan secara bertahap yang dipegang oleh petugas tenaga kesehatan dan buku KIA yang dipegang langsung oleh ibu hamil (Maryunani, 2013).

Peran ibu hamil dalam dalam pelaksanaan $(\mathrm{P} 4 \mathrm{~K})$ yaitu adanya persalinan yang aman, adanya rencana untuk menggunakan alat kontrasepsi setelah melahirkan yang disepakati antara ibu hamil, suami, keluarga dan bidan. Ibu hamil dan keluarganya mempunyai rencana persalinan dan keluarga berencana yang dibuat bersama dengan penolong persalinan. Keluarga mempersiapkan persalinan baik secara material, dan persiapan lingkungan (sosial,budaya). Suami yang dalam masa kehamilan sampai persalinan istrinya selalu berperan aktif dalam meningkatkan kesiapan ibu hamil dalam menghadapi persalinan. Suami juga memiliki peran serta yang besar seperti menentukan persalinan ditolong oleh bidan atau dokter, menabung untuk biaya persalinan, menanyakan kepada bidan, dokter kapan perkiraan tanggal persalinan, meminta penjelasan dalam inisiasi menyusui dini dan ASI Eksklusif, menyiapkan kendaraan jika sewaktu-waktu ibu dan bayi perlu segera ke Rumah Sakit (Maryunani, 2013).

Berdasarkan survei pendahuluan yang dilakukan kepada 15 ibu yang bayinya meninggal saat persalinan dan yang mendapatkan stiker $\mathrm{P} 4 \mathrm{~K}$ dari bidan atau 
puskesmas, dengan metode wawancara pada bulan Mei 2017 di salah satu wilayah di Kabupaten Probolinggo, diperoleh informasi bahwa $66 \%$ ibu hamil belum menempel stiker P4K di rumah, dan 34\% sudah menempel stiker $\mathrm{P} 4 \mathrm{~K}$ di rumah. Padahal penempelan stiker $\mathrm{P} 4 \mathrm{~K}$ ini menjadi panduan teknis bagi tenaga kesehatan yang bertugas di desa/puskesmas dalam mengantisipasi berbagai permasalahan yang terkait dengan Angka Kematian Ibu dan Bayi.

Masih tingginya kematian neonatal di Kabupaten Probolinggo, diduga karena kurangnya peran aktif ibu, suami, keluarga dan masyarakat dalam penerapan $\mathrm{P} 4 \mathrm{~K}$. Perilaku ini mengakibatkan ibu, suami, keluarga dan masyarakat tidak mengenali tanda bahaya dan terlambat membawa bayi sakit ke fasilitas kesehatan. Berdasarkan latar belakang ini, peneliti tertarik untuk meneliti Pengaruh Penerapan Program Perencanaan Persalinan dan Pencegahan Komplikasi (P4K) terhadap Kematian Neonatal di Kabupaten Probolinggo. Diharapkan hasil penelitian ini dapat memberikan kontribusi bagi pemerintah untuk menurunkan angka kematian neonatal melalui penerapan $\mathrm{P} 4 \mathrm{~K}$ secara aktif oleh ibu, keluarga, kader dan masyarakat.

Tujuan penelitian ini yaitu untuk menganalisis pengaruh penerapanProgram Perencanaan Persalinan dan Pencegahan Komplikasi (P4K) terhadap kematian neonatal.

\section{METODE PENELITIAN}

Penelitian ini bertujuan menganalisis pengaruh penerapan $\mathrm{P} 4 \mathrm{~K}$ terhadap kematian neonatal di Kabupaten Probolinggo. Rancang bangun penelitian adalah crossectional. Variabel independen adalah penerapan Program Perencanaan Persalinan dan Pencegahan Komplikasi (P4K) oleh ibu, suami, keluarga dan masyarakat. Sedangkan variabel dependen dalam penelitian ini adalah kematian neonatal. Populasi penelitian adalah seluruh ibu yang mempunyai bayi lahir hidup atau mati (usia 0-28 hari) yang mendapatkan stiker P4K di Kabupaten Probolinggo pada tahun 2017. Teknik sampling menggunakan accidental sampling. Sampel dalam penelitian ini adalah sebagian ibu yang mempunyai bayi lahir hidup atau mati (usia 0-28 hari) yang mendapatkan stiker P4K di Kabupaten Probolinggo pada tahun 2017. Pengumpulan data menggunakan kuesioner dan wawancara. Analisis data menggunakan univariat, bivariat dan multivariat.

\section{HASIL DAN PEMBAHASAN}

Berikut ini disajikan tabel distribusi frekuensi berdasarkan usia ibu hamil, pekerjaan ibu hamil, tingkat pendidikan ibu hamil, paritas ibu hamil, kejadian kematian neonatal, penerapan $\mathrm{P} 4 \mathrm{~K}$ oleh ibu hamil, suami dan keluarga serta pengaruh penerapan $\mathrm{P} 4 \mathrm{~K}$ terhadap kematian neonatal.

Tabel 1. Distribusi Frekuensi Responden Berdasarkan Usia Ibu Hamil, Pekerjaan Ibu Hamil, Tingkat Pendidikan Ibu Hamil, Paritas Ibu Hamil, Kejadian Kematian Neonatal, Penerapan P4K oleh Ibu Hamil, Suami dan Keluarga

\begin{tabular}{lllcc}
\hline No & \multicolumn{1}{c}{ Karakteristik } & \multicolumn{1}{c}{ Indikator } & Frekuensi & Persentase(\%) \\
\hline 1 & Usia ibu hamil & $\leq 20$ tahun & 14 & 28,0 \\
& & $21-25$ tahun & 18 & 36,0 \\
& & $26-30$ tahun & 12 & 24,0 \\
2 & \multirow{4}{*}{ Pekerjaan ibu hamil } & $>30$ tahun & 6 & 12,0 \\
& & Ibu rumah tangga & 36 & 72,0 \\
& & Swasta & 10 & 20,0 \\
& & Guru & 2 & 4,0 \\
3 & Tingkat pendidikan ibu hamil & Wiraswasta & 2 & 4,0 \\
& & SD & 4 & 8,0 \\
& & SMP & 12 & 24,0 \\
& & SMA & 26 & 52,0 \\
4 & Paritas ibu hamil & PT & 8 & 16,0 \\
& & Primipara & 24 & 48,0 \\
5 & Kejadian kematian neonatal & Multipara & 26 & 52,0 \\
& & Ada & 25 & 50,0 \\
& & Tidak ada & 25 & 50,0
\end{tabular}


Berdasarkan Tabel 1, diperoleh hasil mayoritas responden ibu hamil berusia 21 25 tahun (36\%), pekerjaan ibu rumah tangga 36 orang $(72 \%)$, tingkat pendidikan ibu hamil SMA sebanyak 26 orang (52\%), Paritas ibu hamil Multipara 26 (52\%), Kejadian kematian neonatal ada 25 (50\%),

Tabel 2. Distribusi Frekuensi Responden Berdasarkan Penerapan P4K Oleh Ibu Hamil, Suami dan Keluarga

\begin{tabular}{cllcc}
\hline No & \multicolumn{1}{c}{ Karakteristik } & \multicolumn{1}{c}{ Indikator } & Frekuensi & Persentase (\%) \\
\hline 1 & Penerapan P4K oleh ibu hamil & Tidak diterapkan & 29 & 58,0 \\
& & Diterapkan & 21 & 42,0 \\
2 & \multirow{2}{*}{ Penerapan P4K oleh suami } & Tidak diterapkan & 30 & 60,0 \\
& & Diterapkan & 20 & 40,0 \\
\multirow{2}{*}{3} & \multirow{2}{*}{ Penerapan P4K oleh keluarga } & Tidak diterapkan & 28 & 56,0 \\
& & Diterapkan & 22 & 44,0 \\
\hline
\end{tabular}

Berdasarkan tabel 2 diperoleh informasi bahwa masih banyak ibu hamil yang tidak menerapkan $\mathrm{P} 4 \mathrm{~K}$ yaitu 29 orang (58\%), suami yang tidak menerapkan P4K sebanyak 30 orang $(60 \%)$, dan keluarga yang tidak menerapkan P4K sebanyak 28 orang (56\%).

Tabel 3. Pengaruh Penerapan P4K oleh Ibu, Suami Dan Keluarga Terhadap Kematian Neonatal

Penerapan P4K

\section{Penerapan P4K oleh Ibu}

Tidak diterapkan

Diterapkan

Penerapan P4K oleh Suami

Tidak diterapkan

Diterapkan

Penerapan P4K oleh Keluarga

Tidak diterapkan

Diterapkan

\begin{tabular}{|c|c|c|}
\hline Kematian Neonatal & & \\
\hline $\begin{array}{ll}\text { Ada } & \text { Tidak ada }\end{array}$ & $(n=100)$ & $\%$ \\
\hline
\end{tabular}

$\begin{array}{rrrrrrr}21 & 72,4 & 8 & 27,6 & 29 & 100,00 & \mathrm{P}=0,000 \\ 4 & 19,0 & 17 & 81,0 & 21 & 100,00 & \\ 19 & 63,3 & 11 & 36,7 & 30 & 100,00 & \mathrm{P}=0,021 \\ 6 & 30,0 & 14 & 70,0 & 20 & 100,00 & \\ & & & & & & \\ 18 & 64,3 & 10 & 35,7 & 28 & 100,00 & \mathrm{P}=0,022 \\ 7 & 31,8 & 15 & 68,2 & 22 & 100,00 & \end{array}$

Dari hasil data Tabel 3dapat diperoleh informasi bahwa ada kecenderungan semakin ibu tidak menerapkan $\mathrm{P} 4 \mathrm{~K}$, maka kematian neonatal akan semakin terjadi. Hasil uji statistik dengan spearman rho, diperoleh tingkat signifikansi $(\mathrm{p})=0,000<=$ 0,05 . Hal ini menunjukkan bahwa ada pengaruh penerapan $\mathrm{P} 4 \mathrm{~K}$ oleh ibu terhadap kematian neonatal.Diperoleh informasi juga bahwa ada kecenderungan semakin suami tidak menerapkan $\mathrm{P} 4 \mathrm{~K}$, maka kematian neonatal akan semakin terjadi. Hasil uji statistik dengan spearman rho, diperoleh tingkat signifikansi $(p)=0,021<=0,05$. Hal ini menunjukkan bahwa ada pengaruh penerapan P4K oleh suami terhadap kematian neonatal.Selain itu ada kecenderungan juga bahwa semakin keluarga tidak menerapkan $\mathrm{P} 4 \mathrm{~K}$, maka kematian neonatal akan semakin terjadi. Hasil uji statistik dengan spearman rho, diperoleh tingkat signifikansi $(\mathrm{p})=0,022<=$ 0,05 . Hal ini menunjukkan bahwa ada pengaruh penerapan $\mathrm{P} 4 \mathrm{~K}$ oleh keluarga terhadap kematian neonatal.

\section{Pembahasan}

Dari 50 responden ternyata ibu yang tidak menerapkan P4K sebanyak 29 responden (58\%). Suami yang tidak menerapkan $\mathrm{P} 4 \mathrm{~K}$ juga masih banyak yaitu sebesar 30 responden (60\%). Dan dari keluarga yang tidak menerapkan $\mathrm{P} 4 \mathrm{~K}$ sebanyak 28 responden (56\%).Hasil penelitian yang dilakukan oleh peneliti menunjukkan bahwa dari 50 orang ibu yang menjadi responden pada penelitian ini, $50,0 \%$ nya mengalami kematian neonatal dan $50,0 \%$ nya lagi tidak mengalami kematian neonatal.

P4K merupakan kegiatan yang difasilitasi oleh bidan di desa dalam rangka peningkatan peran aktif suami, keluarga dan masyarakat dalam merencanakan persalinan yang aman dan persiapan menghadapi komplikasi bagi ibu hamil termasuk 
perencanaan penggunaan KB pasca persalinan dengan menggunakan stiker sebagai media notifikasi sasaran dalam rangka meningkatkan cakupan dan mutu pelayanan kesehatan ibu dan bayi baru lahir (Kemenkes RI, 2010).

Kematian neonatal menurut ICD10 adalah kematian yang terjadi selama dua puluh delapan hari pertama kehidupan setelah bayi dilahirkan.Kematian neonatal terbagi atas kematian neonatal dini dan kematian neonatal lanjut. Kematian neonatal dini merupakan kematian seorang bayi dari mulai setelah dilahirkan sampai 7 hari pertama kehidupan (0-6 hari). Sedangkan kematian neonatal lanjut adalah kematian bayi setelah 7 hari sampai sebelum 28 hari pertama kehidupan yaitu antara 7-27 hari (WHO, 2006). Masa neonatal adalah masa sejak lahir sampai dengan 4 minggu (28 hari) sesudah kelahiran. Neonatus adalahbayi berumur 0 (baru lahir) sampai dengan usia 1 bulan sesudah lahir. Neonatus dini adalah bayi berusia 0-7 hari.Neonatus lanjut adalah bayi berusia 7-28 hari (Muslihatin, dkk. 2010).

Kematian neonatal dapat disebabkan oleh beberapa faktor, antara lain: infeksi, asfiksia, BBLR, umur ibu, paritas, tempat persalinan, kunjungan antenatal, penolong persalinan, komplikasi ibu, pendidikan ibu, pemberian ASI, sumber air bersih serta keadaan rumah. Banyaknya faktor yang menyebabkan kematian neonatal sehingga perlu adanya peningkatan pelayanan kesehatan, melakukan penyuluhan pada setiap ibu yang sedang hamil dan menyarankan ibu untuk melahirkan ditenaga kesehatan.

Werdiyanti (2017) mengungkapkan bahwa ibu hamil yang tidak menerapkan P4K cenderung mengalami komplikasi. Faktor yang menjadi penghalang ibu hamil dalam menerapkan $\mathrm{P} 4 \mathrm{~K}$ antara lain pengetahuan yang kurang, situasi geografis yang tidak mendukung, budaya sosial, dan dukungan keluarga yang kurang (tidak didukung oleh suami atau keluarga kerena pekerjaan suami di luar daerah).

Noorhalimah (2015) dalam penelitiannya menyarankan bahwa untuk mengatasi kematian neonatal, selain dengan meningkatkan penyuluhan kepada masyarakat tentang kehamilan, persalinan, $\mathrm{KB}$ dan reproduksi yang sehat, peneliti juga menganjurkan untuk mengaktifkan kembali penggunaan stiker P4K. Pernyataan ini diperkuat oleh Sokhiyatun (2013), bahwa bidan desa sudah melakukan koordinasi dan komunikasi dengan baik melalui sosialisasi dan pertemuan rutin yang diselenggarakan di desa terkait program $\mathrm{P} 4 \mathrm{~K}$, namun masih terkendala kurangnya keterlibatan pihak terkait dalam mencapai keberhasilan program $\mathrm{P} 4 \mathrm{~K}$, khususnya dari masyakarat dan perangkat desa. Hal ini disebabkan adanya anggapan bahwa program $\mathrm{P} 4 \mathrm{~K}$ merupakan tanggung jawab dan wewenang tenaga kesehatan, khususnya bidan desa.

Program penempelan stiker P4K ini bukan semata-mata merupakan tanggung jawab bidan tetapi juga merupakan tanggung jawab ibu hamil, suami, keluarga, dan masyarakat. Artinya sebagus apapun program pemerintah yang dicanangkan untuk menurunkan angka kematian neonatal, kalau tidak didukung oleh peran aktif ibu hamil, suami, keluarga dan masyarakat, maka kematian neonatal akan tetap tinggi. Maka sudah seharusnya ibu hamil, suami, dan keluarga berperan aktif dalam penerapan program $\mathrm{P} 4 \mathrm{~K}$.

\section{KESIMPULAN DAN SARAN}

Sebagian besar ibu hamil yang tidak menerapkan P4K sebanyak 29 responden (58\%). Suami yang tidak menerapkan P4K juga masih banyak yaitu sebesar 30 responden (60\%). Keluarga yang tidak menerapkan $\mathrm{P} 4 \mathrm{~K}$ sebanyak 28 responden (56\%). Dari 50 orang ibu yang menjadi responden pada penelitian ini, 50,0\% nya mengalami kematian neonatal dan 50,0\% nya lagi tidak mengalami kematian neonatal. Ada pengaruh penerapan $\mathrm{P} 4 \mathrm{~K}$ oleh ibu hamil, suami, dan keluarga terhadap kematian neonatal.

Disarankan pemerintah daerah dengan karakteristik pedesaan untuk melakukan peningkatan ketersediaan, akses, kapasitas tenaga penolong persalinan dan fasilitas persalinan di wilayahnya. Bagi tenaga kesehatan lebih meningkatkan program upaya pencegahan kematian neonatal yang dilakukan melalui promosi kesehatan dan deteksi dini dimasyarakat seperti pendataan, pemantauan wilayah setempat (PWS), program perencanaan persalinan dan pencegahan komplikasi (P4K), surveilens Kesehatan Ibu dan Anak (KIA), deteksi dini resiko tinggi. Bagi masyarakat, perlu 
dilakukan upaya untuk meningkatkan penggunaan metode Program Perencanaan Persalinan dan Pencegahan Komplikasi (P4K) yang didukung oleh ketersediaan dan kelengkapan fasilitas dan tenaga yang perlukan serta memperhatikan aspek budaya/adat masyarakat setempat. Bagi peneliti selanjutnya, perlu dilakukan penelitian lanjutan tentang peran kader posyandu dalam penerapan Program Perencanaan Persalinan dan Pencegahan Komplikasi (P4K) terhadap kematian neonatal.

\section{REFERENSI}

Maryunani (2013). Program Perencanaan Persalinan dan Pencegahan Komplikasi (P4K). Jakarta: Eka Puspita.

Noorhalimah (2015) Faktor-faktor yang Berhubungan dengan Kematian Neonatal di Kabupaten Taipin (Tinjauan terhadap Pemeriksaan Kehamilan, Penolong Persalinan dan Karakteristik Ibu). Jurnal Publikasi Kesehatan Masyarakat Indonesia. Vol. 2 No. 2, p. 64-71.
Rosyida, dkk (2015) Gambaran Perilaku Ibu Hamil dalam Pelaksanaan Program Perencanaan Persalinan dan Pencegahan Komplikasi (P4K) di Wilayah Kerja Puskesmas Wonokerto 01 Kabupaten Pekalongan. Jurnal Kebidanan. Vol. 07 No. 01, p. 48-56.

Saifuddin dkk. (2009). PelayananKesehatan Maternal \& Neonatal. Jakarta: Yayasan BinaPustaka Sarwono Prawirohardjo.

Sokhiyatun, dkk (2013). Pelaksanaan Program Perencanaan Persalinan dan Pencegahan Komplikasi (P4K) Ditinjau dari Aspek Bidan Desa sebagai Pelaksana di Kabupaten Jepara. Jurnal Manajemen Kesehatan Indonesia. Vol. 1 (01), p. 47-53. 